\title{
Thinking about the Classroom Transformation of the Colleges Ideological and Political Theory Course in the View Of MOOC
}

\author{
Dandan Mao
}

Baicheng Normal University, Baicheng, 137000, China

Email: ksxsh4027@163.com

Keywords: MOOC; Colleges; Ideological and Political; Theory course

\begin{abstract}
MOOC is a new teaching mode under the circumstances of the rapid development of information technology, which not only breaks the traditional classroom teaching mode and provides a way for combining teaching of the traditional classroom teaching and new teaching method, but also puts forward new demands to the traditional classroom teaching method and teaching means. In the view of MOOC, the colleges teaching mode not only has changed in the teaching method, also has changed greatly in the teaching process. Therefore, in the practical teaching the positive role of the MOOC should be paid attention, and it should be better applied to the ideological and political teaching.
\end{abstract}

\section{Introduction}

MOOC is a new teaching mode that relies on the existence of network technology. It is a new teaching mode linking the Internet and teaching activities. At present, the development speed of the MOOC is very quickly, which brings new challenges to the traditional teaching mode and has attracted more and more attention with its extensive development. As a new teaching mode for course, MOOC has broken the drawbacks of the traditional teaching mode, and teaching subject gradually has been changed from teachers as the main parts in classroom teaching to students in classroom teaching, which makes the classroom teaching from the teachers' teaching to the students' learning in the direction of the transition. This article mainly discusses the changes in many aspects of college ideological and political theory course from the perspective of MOOC, from three aspects that the changes from traditional teaching to MOOC teaching, the transformation of teaching methods achieved by MOOC and the transformation of the teaching process realized by MOOC.

\section{From the Traditional Teaching Mode to the New Model Of MOOC Teaching}

Class teaching is the most commonly used teaching method in our country, and the college ideological and political teaching is also taught by this way. At present, the colleges and universities take the way of class-based teaching to carry out ideological and theoretical courses teaching. In fact, in the long time theoretical research of classroom teaching, the researches on classroom teaching have made a series of achievements, the theoretical research results are obtained based on the traditional teaching mode. However, the practice shows that the new attempt of the teaching model of ideological and political education is more conducive to the students' learning. This kind of attempt still regards teachers as the main part of teaching activities, but also redefines the position of students. On the ideological and political classroom teaching, new teaching mode has greatly enhanced the scientific ideological and political teaching[1]. Students are no longer passive acceptance of the teacher taught, but to participate in the teaching activities, teachers improve the enthusiasm of students to participate in classroom teaching by the way of questioning or organization of cooperative learning in the classroom[2].

The ideological and political course is a typical representative of college basic socializing courses, and teaching mode of taking students as the main classroom is the earliest at the end of twentieth century appeared in the public view, which is because the multimedia enabled a large number of web courses emerge gradually. Under the mode of MOOC, teachers will be positioned in 
the teaching content dissemination position by the education and teaching activities, teaching objective has changed from enabling students to learn specific cultural knowledge to teach students the way of learning and cultivate students' learning interest, cultivation of self-learning ability of students in practical teaching in teaching activity is been put an important position[3]. At present, with the rapid popularization of high-tech products, ideological and political teaching and students access to knowledge and ways of learning are exposed a series of contradictions. Therefore, changing the traditional teaching mode in the view of MOOC has become the key subject in the current ideological and political teaching. In the actual ideological and political teaching, we should continue to innovate the teaching mode and make bold attempts to make the teaching mode more in line with the students' learning requirements.

\section{Transformation of Teaching Methods}

The appearance of MOOC speed up the pace of reform of teaching methods, but also facilitate sharing. MOOC social progress will make itself with the knowledge of the ideological and political education, but also for the traditional teaching activity brings some difficulty. Firstly, due to the emergence of MOOC, the traditional teaching mode of students gradually lost interest, led directly to the students in the teaching activities of ideological and political phenomenon is serious; secondly, MOOC teaching mode is in conformity with the requirement of students' learning, has also been questioned that the traditional teaching mode; the MOOC, should take students as the teaching activities of the center, breaking the. MOOC class the main phenomenon has its traditional teacher the new teaching mode in the teaching, and teaching characteristics of open teaching and higher transparency is very prominent, these characteristics directly promote students become The main body of ideological and political classroom activities, with the continuous improvement of teaching technology, MOOC has attracted more and more learners because of the free and well-known experts and scholars teaching and other reasons[4].

The development of MOOC innovates traditional teaching methods and teaching methods. On the one hand, the traditional teaching with the teacher as the main teaching mode should be changed into the fusion of traditional teaching mode and teaching mode of the new direction for. MOOC have complete break our traditional teaching mode in classroom teaching is the main teaching mode in the process of development. However, this is not to say that MOOC teaching is flawless. In fact, MOOC teaching still exist some problems, such as MOOC, although the teaching of convenient communication, but the classroom time is too fragmented. If completely using MOOC teaching method, very easy to make the teaching content more and more fine, more and more only the MOOC system[5]. The new teaching mode and traditional teaching mode combined with open draw factors of excellent elements conducive to teaching and MOOC teaching in the traditional teaching mode, to In the actual classroom teaching, stimulate students' interest in learning, and promote students to develop good study habits.

On the other hand, in the process of teaching video and animation elements added to further realize the transformation of teaching methods. Teachers in traditional classroom teaching mainly adopts the classroom blackboard teaching style. Now, based on the blackboard or play courseware on the innovation of teachers in the teaching process into the video and other factors to achieve the teaching methods and teaching methods the teachers. The traditional teaching in most of the foundation of the presentation will be professor related concepts in textbooks to the students, however, MOOC from the perspective of Ideological and political education pay more attention to the interest of students to participate in classroom, teachers play the new teaching mode of the charm in the teaching process, the students' attention to teaching, the greatest degree stimulate their interest in learning, cultivate their autonomous learning ability marks. MOOC teaching mode is the most obvious change is the subject of teaching, teaching subject from teachers as the main body To the student as the main body of the great changes, and the new model of MOOC characteristics also require teachers in the ideological and political education teaching should pay close attention to students grasp the degree of knowledge.

For example, in the ideological and political teaching process, teachers can adopt the method of 
classroom cooperative learning to grasp the students' learning. Teachers will have different opinions of some problems of distribution to the group, let the students discuss issues related to the group, let them in the process of analysis discusses the results of the record, after the autonomous organization so to speak, not only to stimulate the enthusiasm of students in the classroom, the students have a more profound understanding of the problem. In addition, teachers can also learn to organize the classroom quiz for students to achieve a further grasp, by putting forward the typical problems for students to think about problems, analyze problems, solve the problem in order to achieve, stimulate students' interest in learning. Teachers use MOOC technology for small test, the settings in the teaching process, a knowledge set after several small Q In the process, help students realize the consolidation of knowledge, so that students are more concentrated. The test set can not only enable students to reread the theoretical knowledge, in practical teaching, teachers can also through the quiz master students' degree, make teaching more favorable.

\section{Transformation of Teaching Process}

The classroom of ideological and political courses in the traditional teaching mainly adopts single teacher "teaching" and "learning" of the students a way of teaching. In the teaching process of teachers as the subject of classroom teaching, all the time to the students into political theory knowledge, completely ignore the actual learning situation of students, not very good arouse the students' interest in learning. In the classroom, the teacher through the monotonous teaching content of the concept or principle to teach students, the student is completely passive. However, the teaching activities are actually dialogue activities require teachers and students to participate in, this process is not just important in teaching and learning. More important is the interest in cultivating students to participate in classroom and self-study ability. Only cultivate the students to participate in classroom interest, to enable students to voluntarily participate in the classroom teaching, for real Lay the foundation of classroom teaching is a good effect[6].

The ideological and political teaching, students' learning interest cultivation and classroom participation stimulate is the focus of the teaching content. Teachers should guide students to self-study, to stimulate students' classroom participation plays an important role in the ideological and political teaching, not only to complete the task of classroom teaching, but also allow students to participate in teaching activities the difficulty of classroom teaching, is too large, this is because in a short lecture, broad participation of teachers could not complete the task of teaching and students. The MOOC provides a new way to solve this problem. For example, the use of micro teaching in the curriculum for public network. Compared with the traditional course class time is shorter, more conducive to student learning. Time course of MOOC was fixed on the students to concentrate in a period of time, the students further understand the learning content plays a key role in the teaching process, teachers can guide students before class of micro course preview learning. Students work through online preview learning in micro courses, the classroom learning smoothly has great effect. This is because in the ideological and political classroom teachers can shorten the theory of knowledge, can be selective for some of the problems are focus on the students to understand, have more time to reach the interaction with the students, to stimulate students to participate in classroom teaching of the interest.

Public network is an important measure to optimize the way of teaching in universities. All kinds of high-tech products for students to realize the optimization provides material guarantee for students learning, which directly provides a strong material foundation for active learning in the classroom teaching. Thus, the application of new pattern of MOOC in the teaching process to achieve major changes in the teaching process the transformation of the teaching process. The following two main advantages: first, the interaction between teachers and students, learning greatly before students in classroom teaching, the teachers on the time to explain the theory of knowledge, most of the class time actually became a teacher and students or between students and students in cooperative learning and discussion. The second time. Changed the specific process of classroom teaching. The traditional teaching mode for teachers to import knowledge, the knowledge, then the system of knowledge To explain, the use of MOOC to enable students to further deepen the 
understanding of the use and explanation of the theory of knowledge, make the teaching process from the original speaker teachers mainly transition to the student asked the teacher questions direction. However MOOC will be applied to the new teaching mode of Ideological and political education teaching, pay attention to the following aspects: teachers and students to understand further, through the understanding of the learning needs of students, reasonable teaching tasks, achieve teaching objectives; secondly, to pay attention to the design of the teaching process. Teachers only according to the learning needs of students to develop teaching ideas and corresponding to the specific situation of students, help students develop the basis of progress in the teaching process, in order to better the completion of teaching objectives.

With the continuous development of information technology, the combination of MOOC and classroom teaching has become an important content of the reform of teaching mode. This teaching model not only pay attention to guidance of teachers in the classroom teaching, students will also be located in the center of the classroom teaching. The specific performance of cultivate interest in learning by teachers in the classroom teaching guidance of students. Make students play the subjective initiative of autonomous learning. The ideological and political education courses are different compared with the general curriculum, this is because of the ideological and political education curriculum gradually achieved from textbooks to transition to teaching. Teachers not only bear the task of teaching the basic knowledge of Ideological and political theory, but also in the process of teaching into the correct the three. The ideological and political education is very complicated, which requires teachers in the teaching process to teaching content according to different choices of more suitable The methods of teaching, mobilize the classroom atmosphere, stimulate students to participate in classroom learning.

\section{Conclusion}

MOOC is the progress of the times brought to break the traditional teaching mode of the new changes, plays a very important role in the open class university teaching activities. The ideological and political theory is to a public class learning of college students, MOOC not only the innovation of Ideological and political theory education teaching mode, and further the reception of the ideological and political course teaching the effect of. MOOC is not very significant to the traditional teaching mode full veto to college students, but absorbed the favorable factors to teaching in traditional classroom teaching, and the integration of high technology, will both combine together for the teaching service, promote the continuous upgrading of innovative teaching methods and teaching ideas.

\section{References}

[1] Wang Yuexi, Li Hongxing. Analysis of the theoretical basis of introducing service learning into Ideological and Political Theory Courses [J]. Leading Journal of Ideological \& Theoretical Education. 2016 (11)

[2] Li Qingxia. Challenges and Countermeasures of the right of discourse of Ideological and political theory course in Colleges and Universities [J]. Leading Journal of Ideological \& Theoretical Education. 2016 (11)

[3] Shao Ximei. The opportunities and challenges of the ideological and political theory course under the background of "Internet plus"[J]. Journal of Shandong Administration College. 2016 (06)

[4] Liu Xin. Innovation of traditional classroom teaching reform of Ideological and political theory course in MOOC [J]. Reform and Opening Up. 2017 (08).

[5] Zhou Lili; Cai Liang. The effectiveness of the ideological and political theory teaching from the perspective of MOOC [J]. School of Party Construction and Ideological Education. 2017 (01)

[6] Liu Weixia. Research on the teaching reform of Ideological and political theory course in Colleges and universities from the perspective of MOOC [J]. Journal of Hubei Correspondence 
University. 2017 (08) 